\title{
Perancangan Board Game Sebagai Media Pembelajaran Mitigasi Kebakaran Untuk Anak Sekolah Dasar Usia 8-12 Tahun Di Surabaya
}

\author{
Firdaus Setyanugrah, dan Denny Indrayana Setyadi. \\ Jurusan Desain Produk Industri, Fakultas Teknik Sipil dan Perencanaan, Institut Teknologi Sepuluh \\ Nopember (ITS) \\ Jl. Arief Rahman Hakim, Surabaya 60111 Indonesia \\ e-mail: denny@prodes.its.ac.id
}

\begin{abstract}
Abstrak-Surabaya merupakan satu kota dengan tingkat kejadian kebakaran yang tinggi, dimana minimal hampir setiap satu hari sekali dengan rata-rata 5 hingga 10 kali kebakaran dapat terjadi di setiap sudut kota Surabaya. Pendidikan penanggulangan dan pencegahan bencana sangat diperlukan bagi masyarakat khususnya anak-anak yang menjadi sosok paling rentan jika bencana tersebut terjadi. Perlunya diadakan sebuah pemahaman bagi anak-anak tentang tanggap bahaya kebakaran membuat materi tersebut sudah sewajarnya diberikan untuk anak. Dalam melakukan perancangannya, metodologi yang digunakan penulis dalam penelitian ini adalah observasi, kuesioner, depth interview dengan kepala operasional pemadam kebakaran dan juga guru sekolah dasar, serta studi literatur tentang mitigasi kebakaran untuk anak dan juga studi literatur tentang board game. Dengan adanya penelitian menggunakan media board game ini akan menjadi media edukasi tentang pembelajaran mitigasi bagi anak-anak.juga dapat menjadi sarana pengetahuan dan pelatihan kepada anak-anak untuk dapat mengenal dan mencegah kebakaran di lingkungan sekitar
\end{abstract}

Kata Kunci-media pembelajaran, permainan papan, mitigasi, kebakaran

\section{PENDAHULUAN}

$\mathrm{K}$ EBAKARAN merupakan ancaman bencana yang tidak dapat dianggap remeh. Bencana kebakaran mampu menimbulkan dampak yang dapat dibilang sangat mengkhawatirkan, mulai dari dampak psikologis serta sosial masyarakat. Kebakaran menjadi salah satu hal yang dapat sering terjadi khususnya diwilayah perkotaan padat penduduk di Surabaya. Kebakaran merupakan bencana yang menurut Badan Penanggulangan Bencana sebagai bencana ke-4 terbesar di Indonesia dan bencana terberat ke 2 yang terjadi di Surabaya.Kebakaran di wilayah Surabaya sendiri cukup mengkhawatirkan, dimana minimal hampir setiap satu hari sekali dengan rata-rata 5 hingga 10 kali kebakaran dapat terjadi di setiap sudut kota Surabaya. Jumlah kebakaran di Surabaya masih terbilang tinggi. Angka kejadian pada tahun 2014 naik menjadi 596 kejadian dibandingkan dengan tahun sebelumnya yang hanya 433 kejadian. Dalam empat bulan terakhir di tahun 2014 jumlah kebakaran di kota Surabaya terus meningkat. Sesuai data yang ada, terjadi peningkatan jumlah setiap bulannya.

Kebakaran yang terjadi di Surabaya jika melihat data bersifat fluktuatif namun cenderung meningkat. Kebakaran pada tahun 2015 hingga bulan Oktober mencapai 446 kejadian, dengan jumlah kejadian tiap bulannya naik dari tahun sebelumnya. Hal ini disebabkan oleh beberapa faktor, diantaranya hubungan arus listrik, kebakaran yang disebabkan oleh pembakaran sampah secara sembarangan, serta ledakan gas didalam rumah maupun gedung. Hal tersebut oleh petugas Pemadam Kebakaran Surabaya dinilai menjadi pemicu utama penyebab kebakaran.

Kesadaran masyarakat tentang bagaimana mengetahui dan mencegah kebakaran dirasa kurang, melihat angka kebakaran di wilayah Surabaya masih terbilang cukup tinggi. Oleh karena itu Dinas Pemadam Kebakaran kota Surabaya melakukan program sosialisasi kepada masyarakat tentang tindakan pencegahan dan pengurangan resiko kebakaran dilingkungan sekitar. Selain kepada masyarakat, sosialisasi mitigasi ini juga dilakukan kepada anak-anak sekolah dasar yang ada di Surabaya. Program sosialisasi kepada anak ini merupakan salah satu program yang didukung oleh Kementerian Pendidikan sebagai langkah awal untuk mengurangi resiko bencana [1].

Suatu bencana terjadi karena adanya pertemuan antara bahaya (hazard) dan kerentanan (vulnerability) dan ditangani oleh kemampuan (capability) untuk menanggulanginya. Kemampuan penanggulangan sangat diperlukan karena menjadi salah satu faktor penting untuk dapat menghindari kejadian serupa. Upaya peningkatan kapasistas kemampuan seseorang dalam menanggulangi bencana dapat dilakukan melalui sosialisasi informasi, pelatihan, dan simulasi di daerah potensi bencana [2]. Pendidikan penanggulangan dan pencegahan bencana sangat diperlukan bagi anak-anak yang menjadi sosok paling rentan jika bencana tersebut terjadi, dan selain itu anak-anak juga menjadi sosok yang dirasa sangat terkena dampak khususnya dampak psikologi jika terjadi bencana [3].

Menurut Dr. Heru Susetyo LLM (Visiting Researcher Disaster Prevention Research Inst Kyoto University \& Chulalongkorn University), "pendidikan mitigasi bencana pada anak dilakukan dengan tujuan memberi informasi pada anak tentang pengetahuan mengenai bencana, memberi pemahaman tentang perlindungan secara sistematis, membekali anak melalui practical training bagaimana melindungi dirinya dan bagaimana mereka bisa merespon bencana tersebut secara tenang, tepat dan cepat. 
Perancangan media pembelajaran mitigasi ini menerapkan sebuah metode pembelajaran dengan pendekatan melalui game. Game membantu anak dalam meningkatkan kecerdasan otak. Melalui media pembelajaran berbasis game, anak mampu mendapat ilmu berupa teori dan juga praktek berupa pengalaman secara tidak langsung, dimana game mampu memberikan dan meningkatkan kreatifitas anak-anak. Dengan media pembelajaran berupa game, anak mampu meningkatkan kinerja motorik mereka sehingga mereka dapat berpikir dan bertindak dengan benar dalam satu waktu [4].

Dengan menggunakan media pembelajaran berupa permainan, anak dapat memahami mitigasi bencana melalui belajar sambil bermain. Pengalaman dalam permainan simulasi dapat digunakan untuk melatih perkembangan motorik anak dan meningkatkan pemahaman serta meningkatkan respon anak-anak dalam upaya pengurangan risiko bencana.

\section{A. Batasan Masalah}

1) Perancangan ini hanya terfokus pada materi konten mitigasi yang diperuntukkan untuk anak-anak sekolah dasar

2) Output yang dihasilakn pada perancangan ini adalah satu set board game dengan judul Damkar lengkap dengan item permainan seperti kartu, pion dan koin permainan.

B. Rumusan Masalah

"Bagaimana merancang board game yang mampu menjadi sarana edukasi tentang pengenalan dan pencegahan kebakaran sebagai media pembelajaran tindakan mitigasi bencana untuk anak usia 8-12 tahun?"

C. Tujuan

"Memberikan infromasi tentang tindakan mitigasi kebakaran melalui proses tahapan pengenalan dan pencegahan awal kebakaran, sehingga anak-anak memiliki pengetahuan, dan pemahaman secara tidak langsung dalam mencegah kebakaran terjadi di lingkungan sekitar melalui perancangan board game mitigasi kebakaran"

\section{TINJAUAN PUSTAKA}

\section{A. Landasan Teori}

Belajar adalah suatu proses kompleks yang terjadi pada semua orang dan berlangsung seumur hidup. Proses belajar dapat terjadi kapan saja dan di mana saja, terlepas dari ada yang mengajar atau tidak. Salah satu pertanda bahwa seseorang telah belajar adalah adanya perubahan tingkah laku dalam dirinya. Perubahan tingkah laku tersebut menyangkut baik perubahan yang bersifat pengetahuan (kognitif), keterampilan (psikomotor), maupun yang menyangkut nilai dan sikap (afektif). Perubahan tersebut terjadi sebagai akibat interaksi individu dengan lingkungannya, dimana perubahan itu harus bersifat relatif permanen, tahan lama dan menetap, tidak berlangsung sesaat saja.[5]

Asosiasi Pendidikan Nasional mengartikan media sebagai bentuk-bentuk komunikasi, baik yang cetak maupun audio visual, yang dapat dilihat, didengar, dan dibaca. Jadi Apabila media itu membawa pesan-pesan atau informasi yang bertujuan instruksional atau mengandung maksud-maksud pengajaran maka media itu disebut Media Pembelajaran.[6]

\section{B. Karakteristik Media Pembelajaran}

Secara umum media pembelajaran memiliki kegunaankegunaan untuk memperjelas penyajian pesan agar tidak terlalu bersifat verbal (berbentuk kata-kata tertulis atau lisan), dan mampu mengatasi keterbatasan ruang, waktu, daya indera, seperti objek yang terlalu besar dapat digantikan dengan gambar atau model, lalu konsep yang terlalu luas dapat divisualisasikan dalam bentuk film atau gambar. Media-media yang digunakan dan diterapkan untuk anak usia sekolah dasar harus berdasarkan pada kemampuan atau potensi yang dikembangkan oleh anak.

Dalam usaha memanfaatkan media sebagai alat bantu, Edgar Dale mengadakan klasifikasi pengalaman menurut tingkat dari yang paling konkret ke yang paling abstrak. Klasifikasi tersebut adalah kerucut pengalaman (cone of experience) dan pada saat itu dianut secara luas dalam menentukan alat bantu apa yang paling sesuai untuk pengalaman belajar tertentu.

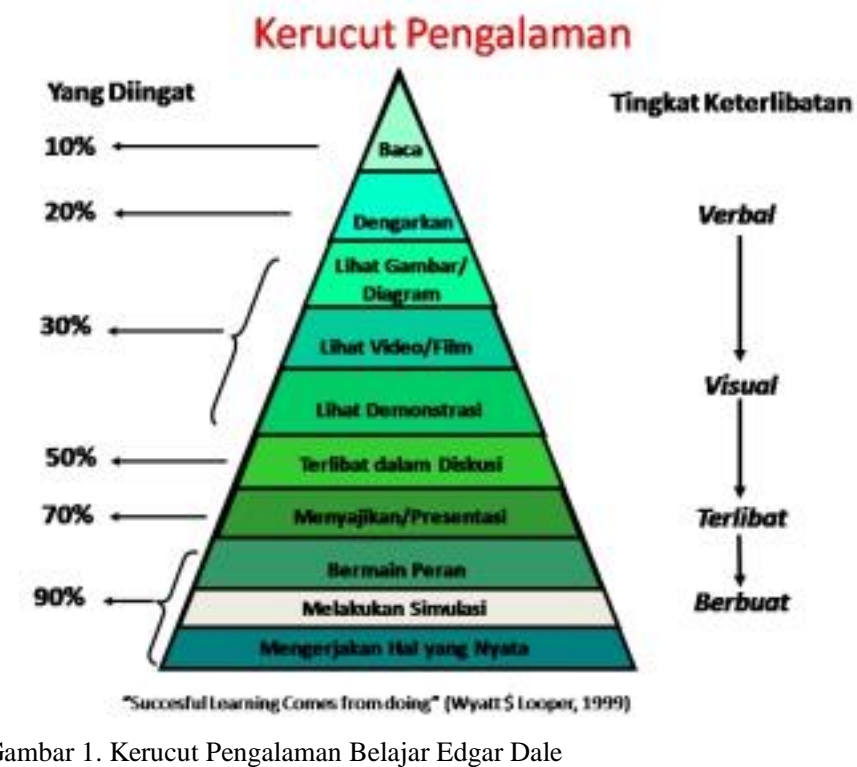

Karakteristik media ini sebagaimana dikemukakan oleh Kemp (1975) merupakan dasar pemilihan media sesuai dengan situasi belajar tertentu. Karakteristik media juga dapat dilihat menurut kemampuan membangkitkan rangsangan indera penglihatan, pendengaran, perabaan, pengecapan, maupun penciuman [7].

\section{Tinjauan Materi Mitigasi Kebakaran}

Manajemen bencana adalah suatu proses berlanjut untuk meningkatkan kualitas penanganan dan pencegahan terhadapa bencana. Menurut University of Wisconsin mendefinisikan manajemen bencana sebagai "the rage of activities designed to maintain control over disaster and emergency situation and to provide a framework for helping at risk persons to avoid or recover from the impact of disaster".[8] Manajemen bencana perlu diadakan dan ditingkatkan seiring dengan perubahan yang terjadi pada lingkungan sekitar.

Pengajaran tersebut dimulai oleh beberapa sekolah. 
penyelenggaraan pengurangan resiko bencana dilakukan sebagai bagian dari tindakan penanggulangan bencana dan mewajibkan sekolah untuk melaksanakan kegiatan pengajaran tersebut. Hal itu sebagai bagian dari pendidikan kebencanaan yang dijalankan oleh Mendiknas. Materi pembelajaran tindakan mitigasi terbagi menjadi 4 proses tahapan diantaranya sebagai berikut

1) Pengenalan

Pada tahapan ini anak-anak diajarkan untuk melakukan pengenalan terhadap keadaan lingkungan sekitar dan melakukan pengenalan terhadap berbagai macam sumbersumber kebakaran.

\section{2) Pencegahan}

Pada Tahap ini anak-anak mulai melakukan kegiatan belajar yang difokuskan pada tahap pencegahan. Selain informasi anak-anak juga di tuntut untuk mengerti bagaimana cara bertindak melakukan pencegahan agar tidak terjadi kebakaran.

3) Penanganan

Pada tahap penanganan adalah tahap dimana mulai adanya kontak fisik dengan benda-benda yang berpotensi terjadi kebakaran, bagaimana cara mengatasinya dan mengendalikan kebakaran sehingga tidak menimbulkan korban.

4) Pemulihan

Pada tahapan ini diajarkan cara melakukan pertolongan pertama dan tindakan medis yang dilakukan sehingga korban kebakaran dapat segera tertolong.

Pada beberapa tahapan tersebut, untuk pengajaran pada anak-anak hanya dilakukan melalui dua tahapan yaitu tahap pengenalan dan pencegahan. Melalui poin poin pengajaran tersebut nantinya disesuaikan dengan tatanan permainan yang akan dikemas secara edukatif.

\section{Studi Eksisting Materi}

Dalam Pengambilan materi konten penulis melakukan uji konten sesuai dengan modul ajar yang ada. Konten mitigasi berkisar antara pengenalan awal dan pencegahan dan secara keseluruhan telah dijelaskan pada modul ajar namun kurang begitu diminati oleh anak-anak. Selain melalui modul ajar, materi konten juga diambil dari hasil wawancara dengan pihak terkait mengenai tata cara penyelamatan diri awal pada saat terjadi kebakaran.

\section{E. Acuan Komparator}

Flash point adalah jenis permainan papan (board game) yang memiliki tema serupa berupa kebakaran namun materi konten yang disajikan berbeda. Dalam permainan ini pemain diharuskan menyelamatkan korban kebakaran yang terjebak didalam suatu rumah.

Ticket to Ride adalah permainan papan yang digunakan sebagai acuan komparator dalam menentukan konsep gameplay dan juga mekanisme permainan papan. Dalam permainan papan ini pemain diharuskan untuk menyusun kereta berdasarkan kartu dan harus mengingat gerbong kereta mana yang dapat melaju ke jalur berikutnya.

\section{METODOLOGI PERANCANGAN}

\section{A. Jenis dan Sumber Data}

Dalam perancangan board game ini penulis menggunakan pendekatan melalui metode kualitatif dan metode kuantitatif dalam melakukan proses riset terhadap topik yang dipilih. Metode kualitatif digunakan sebagai acuan penulis untuk mendapatkan materi board game yang sesuai dengan tema, kemudian mencari kriteria desain yang sesuai dengan target audiens.

\section{1) Data Kuantitatif Kuesioner}

Kuesioner yang dibuat terdiri dari kuesioner problematika dan kuesioner minat dan kegemaran dan karakteristik responden. Dari data yang dianalisis akan muncul karakteristik dari responden. Kuesioner dibagi kedalam beberapa kategori kelas berdasarkan tingkatan kelas siswa Sekolah Dasar. Kuesioner dibagi ke beberapa Sekolah Dasar, diantaranya, SDN Pacar Keling VI Surabaya, SD Muhammadiyah 4 Surabaya, SDN Kaliasin I Surabaya.

\section{2) Data Kualitatif Depth Interview}

Melalui depth interview penulis mampu menemukan pokok permasalahan serta solusi efektif dalam menyelesaikan permasalahan. Narasumber terkait dari kegiatan depth interview meliputi pihak terkait dari topik penelitian serta pihak-pihak kompeten dalam hal yang berkaitan dengan topik yang dipilih oleh penulis. Diantaranya adalah petugas satuan Pemadam Kebakaran Surabaya serta praktisi pendidikan yang terkait dengan masalah pengajaran dan pembelajaran terhadap siswa didik di sekolah.

\section{3) Data Kualitatif Observasi}

Observasi dilakukan kepada anak anak kelas 4, 5, 6 Sekolah Dasar di Surabaya, yang meliputi, SDN Pacar Keling 6 Surabaya, SDN Kaliasin I Surabaya, Observasi bertujuan untuk melihat karakteristik personal dari masing-masing siswa di sekolah dasar, untuk mengetahui apa yang mereka suka, dan sebagai acuan untuk penulis dalam menentukan kriteria dan konsep desain yang akan dibuat karena nantinya mengacu pada hasil yang didapat dari responden. Observasi ini dilakukan untuk menggali data, mencari kegemaran, menentukan konsep awal, dan menentukan kriteria board game desain.

\section{4) Data Sekunder}

a. Data kebakaran selama 4 tahun terakhir di wilayah surabaya dari Dinas Pemadam Kebakaran Kota Surabaya

b. Data jurnal literatur buku yang berkaitan dengan topik penelitian

c. Dokumentasi kegiatan belajar mengajar serta dokumentasi dari kegiatan penelitian dan survei pengambilan data

d. Internet sebagai media dalam mencari referensi problematika, studi komparator dan referensi yang terkait dengan penelitian.

e. Media eksisting dan komparator yang terkait dengan topik penelitian 


\section{B. Teknik Sampling}

Teknik sampling digunakan agar perancangan media ini memiliki sasaran yang tepat dengan mempertimbangkan selera target audiens, mulai dari tampilan visual serta tingkat pemahaman materi yang disesuaikan dengan karakteristik target audiens. Penyebaran kuesioner dilakukan di surabaya selama kurag lebih 3 hari dengan masing masing 3 sekolah berbeda.

\section{Segmentasi Demografi \\ $\square$ Jenis Kelamin : Laki-laki dan Perempuan \\ $\square$ Umur $\quad: 8-12$ tahun \\ Domisisli : Kota Surabaya \\ $\square$ Pendidikan : Siswa-siswi Sekolah Dasar di Surabaya \\ kelas 4, 5, 6 SD. \\ Segmentasi Geografi}

Anak-anak sekolah dasar di surabaya dengan usia 8-12 tahun. Bersekolah di SDN Pacar keling VI Surabaya, SD Muhammadiyah 4 Surabaya, SDN Kaliasin I Surabaya dengan jenjang pendidikan kelas 4, 5, 6 .

Segmentasi Psikografi

- Bergerak aktif

- Bermain menjadi salah satu kegiatan utama

- Bermain sambil berolahraga untuk anak laki-lakil

- Bermain dengan teman kelompok

- Mengikuti perkembangan zaman

- Meyukai hal baru dan memiliki rasa ingin tahu yang besar

- Tingkat sosialisai tinggi dikarenakan adanya pembelajaran di sekolah

- Menyukai hal hal yang bersifat penelitian

\section{Sampel responden}

$\begin{array}{ll}\square \text { Jumlah Responden } & : \text { 229 Responden } \\ \square \text { Jenis Kelamin } & : \text { Laki laki dan Perempuan } \\ \square \text { Umur } & : \text { 8-12 Tahun } \\ \square \text { Pendidikan } & : \text { Siswa siswi sekolah dasar kelas 4, 5, } 6 .\end{array}$

\section{Depth Interview}

Depth interview dilaksanakan pada sebanyak 3 kali pada tanggal 12 Oktober 15 Oktober, dan 20 Oktober 2015. Depth interview berlangsung di Surabaya. Pihak-pihak yang menjadi narasumber dalam proses depth interview meliputi :

1) Bpk. Nur wahyudi, Kepala Bidang Operasional Dinas Pemadam Kebakaran Kota Surabaya.

2) Bpk. Juwono, Staff Operasional dan penanganan tanggap cepat Kebakaran, Dinas Pemadam Kebakaran Kota Surabaya.

3) Ibu. Sujilah, S.Pd, M.Si, Kepala sekolah SDN Kaliasin I Surabaya

4) 10 anak anak kelas 4,5 6 Sekolah Dasar yang menjadi area penelitian penulis di surabaya.

\section{Observasi}

Observasi dilakukan dengan cara mengamati kegiatan belajar dan bermain anak-anak ketika berada di sekolah, bagaimana materi dan penyampaian pesan yang dimengerti oleh anak-anak. Observasi ini dilakukan untuk menggali data, mencari kegemaran, menentukan konsep awal, dan menentukan kriteria board game desain.

Selain itu observasi juga mengamati dan memberikan test uji coba serta pertanyaan kepada 10 orang anak tiap masing masing sekolah. Observasi dilakukan selama kegiatan belajar berlangsung, untuk kegiatan uji coba dan sesi pertanyaan dilakukan ketika anak istirahat kelas dan sepulang sekolah. Test uji coba meliputi uji coba board game yang ada seperti monopoli, ular tangga, 7 wonders, ticket to ride, flashpoint, Pandemic, heroes of normadine, waroong wars, UNO.

\section{KONSEP DESAIN}

Konsep desain dari perancangan board game ini adalah mensimulasikan diri sebagai petugas pemadam kebakaran yang berusaha memadamkan halangan berupa titik api. Konsep board game-nya sendiri menggunakan gameplay dari kategori classic board. Dengan menggunakan sistem petak dan alur yang menuntun pemain hingga ke garis akhir. Disertai dengan beberapa bantuan dan rintangan berupa informasi dan pertanyaan yang harus dilakukan oleh pemain untuk dapat mencapai garis akhir.

Penggunaan konsep gameplay kategori classic board game dikarenakan kemudahan dalam pemahaman tata cara permainan untuk anak-anak. Aktivitas yang dilakukan oleh pemain nantinya adalah mendapatkan informasi yang berisi tentang konten tindakan pencegahan kebakaran, kemudian menjawab pertanyaan yang di simbolkan sebagai pin bergambar titik api yang artinya adalah pemain diwajibkan untuk menjawab pertanyaan yang tertera untuk dapat memadamkan api.

Pemilihan konsep permainan yang membuat anak seolaholah menjadi seorang pemadam kebakaran juga berkaitan dengan penamaan untuk permainan papan dan logo permainan papan yang akan dibuat. "DAMKAR" adalah nama permainan yang dipilih dikarenakan keterikatan dengan konsep yang digunakan sebagai dasar permainan papan ini. Pemilihan nama Damkar adalah kependekan dari "Pemadam Kebakaran" yang mampu merepresentasikan tujuan, konten serta konsep utama permainan ini.

\section{A. Strategi Media}

Media pembelajaran board game dipilih karena pendekatan yang efektif bagi anak-anak adalah belajar sambil bermain. Menurut Praktisi tumbuh kembang anak Lely Tobing mengatakan bahwa "boardgame mampu mengajarkan banyak hal. Boardgame juga dapat melatih konsentrasi dan daya ingat anak. Untuk anak usia sekolah, boardgame dapat melatih anak memecahkan masalah, berstrategi, serta berpikir kreatif dan kritis".[9] Dengan media board game ada tiga aspek yang tercakup di dalamnya, yaitu aspek visual (gambar), audio (berdiskusi dan tanya jawab), serta afektif (sikap).

\section{B. Strategi Komunikasi}

Pendekatan yang dilakukan untuk anak usia 8-12 tahun dapat dilakukan dengan berbagai cara, yang pertama adalah kelompok bermain. Permainan board game mitigasi kebakaran ini dimainkan oleh 4 hingga 6 orang pemain, Strategi yang kedua adalah dengan menerapkan konsep game berbasis 
sistem belajar dan bermain. Pemberian materi disertai dengan kegiatan bermain akan membuat anak-anak merasa seakan sedang bermain dan bukan belajar, Strategi komunikasi yang ketiga adalah pemilihan bahasa yang digunakan dalam permainan. Target usia pemain adalah anak-anak usia 8-12 tahun, maka gaya bahasa yang digunakan adalah percakapan bahasa Indonesia yang diucapkan sehari-hari, dan strategi yang terakhir adalah dengan menerapkan pemberian reward dan punishment terhadap para pemain.

\section{Konsep Keyword}

"SAFETY FIRST", konsep keyword tersebut menjelaskan tentang bagaimana anak-anak dapat bermain dengan api tanpa harus takut ketika mereka tahu semua informasi dan selalu mengutamakan keselamatan. Konsep tersebut juga menjelaskan tentang bagaimana anak-anak menyikapi diri mereka untuk selalu melihat dan mengutamakan keselamatan diri dan sekitar ketika melihat sebuah kebakaran.

Bagaimana anak-anak melihat kebakaran dengan cara yang menyenangkan untuk diatasi ketika mereka tahu semua informasi yang dibutuhkan untuk mencegah, dan mengatasi kebakaran, sehingga ketika kejadian kebakaran terjadi di sekitar lingkungan, anak-anak dapat menghadapi dengan tenang dan tidak menimbulkan kepanikan.

\section{Kriteria Visual}

\section{- Warna}

Penggunaaan warna dalam perancangan board game dipilih berdasarkan warna yang menjadi dominasi seragam dari petugas pemadam kebakaran. Warna dominan yang digunakan meliputi warna jingga, biru tua , dan kuning, sedangkan warna pendamping yang digunakan meliputi merah dan biru muda. Warna yang dominan dapat menjelaskan tentang tema board game ini. Pemilihan warna diantaranya warna jingga, biru tua, biru langit, kuning, dan merah. Warna tersebut memiliki arti tersendiri dikaitkan dengan pemadam kebakaran.

\section{- Layout}

'Konsep layout yang digunakan adalah penggambaran ilustrasi diletakkan pada tengah kartu dengan penjelasan atau keterangan berada dibawah kartu. Dominasi layout lebih kepada penggambaran visual ilustrasi.

\section{- Gaya Gambar}

Penggambaran ilustrasi yang sesuai dengan target audiens adalah ilustrasi dengan gaya gambar kartun. Kartun yang dimaksud disini adalah kartun 2 dimensi dengan pewarnaan yang block dan juga pemberian bayangan sederhana, kemudian penggunaan outline tebal sebagai garis penjelas pada ilustrasi.

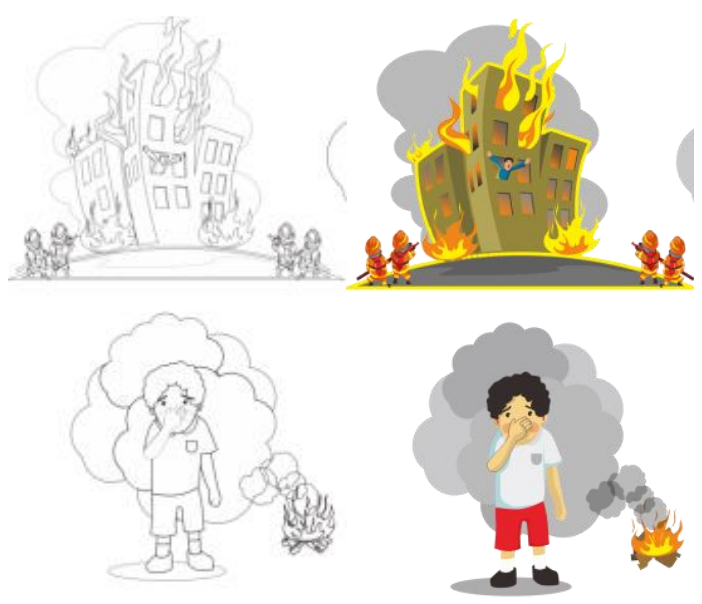

Gambar 8. Tampilan Gaya Gambar

- Tipografi Penulisan

Pemilihan jenis font yang digunakan dalam perancangan ini adalah jenis font san-serif. Dipilihnya font dengan jenis itu dikarenakan font dengan jenis tersebut sangat mudah dalam hal keterbacaan dan gaya hurufnya cukup menarik dan lucu sehingga dapat menarik perhatian anak-anak. Ukuran dalam penggunaan font untuk setiap penulisan keterangan maupun headline pada board game ini berkisar 8pt hingga 16pt. Font dengan jenis san-serif yang dipakai antara lain

Janda Manatee Solid

\section{AaBbCcDdEeff 12345}

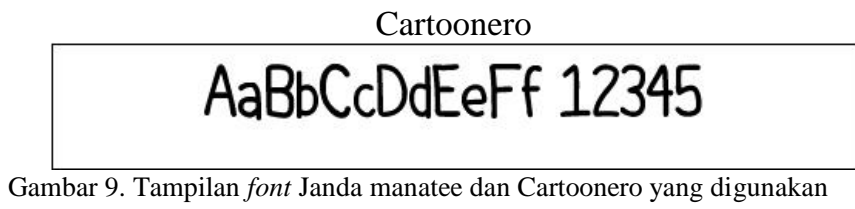

\section{IMPLEMENTASI DESAIN}

\section{A. Papan Permainan}
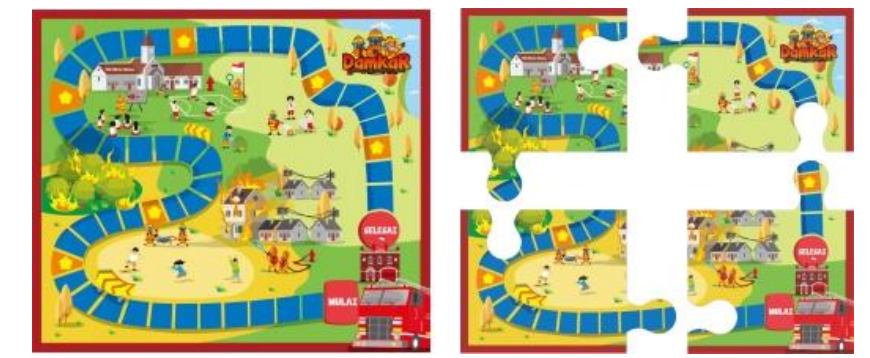

Gambar 10. Tampilan papan permainan

Desain utama papan bermain menggambarkan ilustrasi sesuai dengan tema, dengan skenario cerita dimulai dari kantor pusat pemadam kebakaran dan berakhir kembali ke kantor pusat pemadam kebakaran. Desain papan permainan utama dibuat kedalam 4 panel puzzle yang nantinya disusun oleh pemain menjadi satu bagian. 


\section{B. Kartu Permainan}
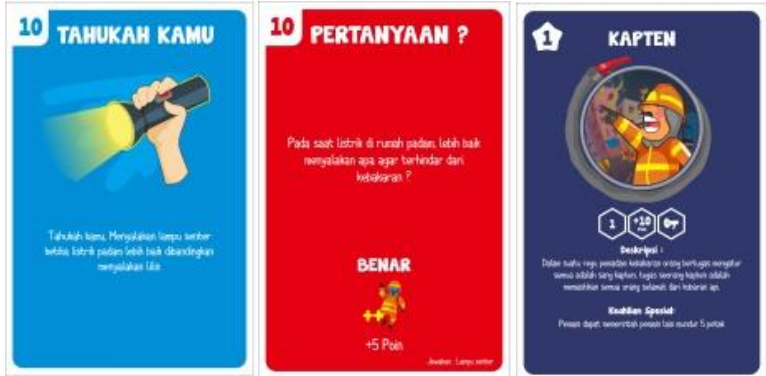

Gambar 11. Tampilan Kartu Permainan

Kartu menjadi komponen paling penting dalam permainan papan ini. Kartu tersebut nantinya akan membantu tiap pemain dalam menyelesaikan permainan. Dalam permainan papan ini terdapat 3 kartu yang terdiri dari kartu informasi, kartu pertanyaan atau soal, kartu profesi atau kartu kekuatan. Ketiga kartu tersebut dibedakan berdasarkan warna dan konten didalamnya.

\section{Pion Permainan}

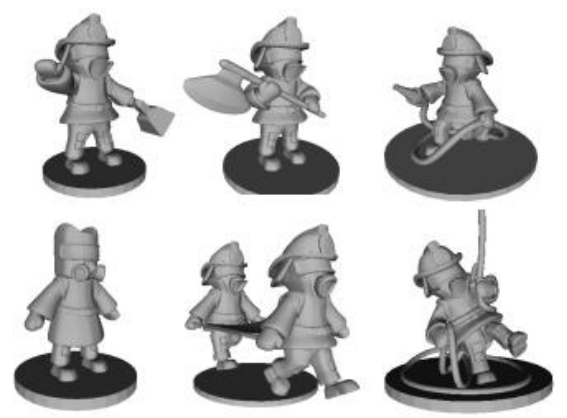

Gambar 12. Tampilan bentuk pion permainan

Pion atau bidak dalam board game mitigasi ini adalah sosok karakter yang sangat khas yang menjadi ciri khas dari pemadam kebakaran. Pemilihan karakter tersebut dengan alasan karena sosok seorang pemadam kebakaran adalah sosok yang tepat untuk mendeskripsikan tema dari board game ini. Memiliki ukuran tinggi $5 \mathrm{~cm}$ dan lebar $3 \mathrm{~cm}$

\section{Komponen Pendukung lain}

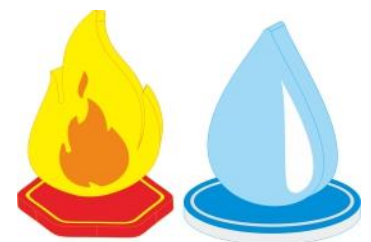

Gambar 13. Tampilan titik halangan permainan

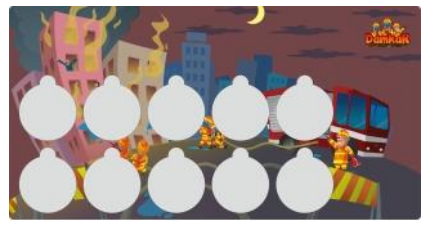

Gambar 14. Tampilan papan koleksi nilai

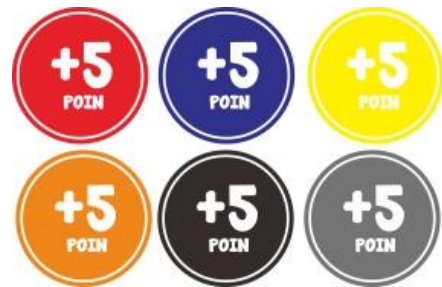

Gambar 15. Tampilan koin nilai permainan
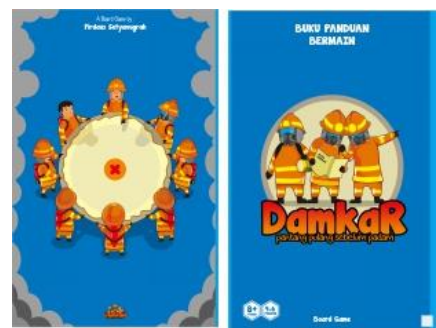

Gambar 16. Tampilan Buku petunjuk manual

Komponen pendukung permainan papan ini menjadi satu bagian dari permainan yang dapat ditemukan dalam satu set kemasan. Komponen ini berfungsi agar jalannya permainan dapat terjaga dengan teratur dan baik. Masing-masing komponen mempunyai peran dan fungsinya sendiri sehingga permainan dapat selalu berjalan tanpa halangan.

\section{KESIMPULAN}

\section{A. Kesimpulan}

Permainan papan (board game) dengan judul damkar ini merupakan sebuah media yang mampu membantu anak dalam memahami dan mempelajari tindakan mitigasi kebakaran. Dengan menggunakan konsep gameplay utama Memory play, anak-anak dapat mengingat dan menghafal kejadian-kejadian yang terjadi pada saat itu, serta dapat menemukan pemecahan masalahnya.

Final desain dari perancangan permainan papan damkar ini telah diuji cobakan kepada target audiens yaitu anak-anak dengan batas usia 8 hingga 12 tahun. Uji coba desain dilakukan kedalam tiga tahap, tahap pertama uji coba untuk menguji materi konten, kemudian uji coba mekanisme permainan, dan uji coba desain final atau playtest akhir untuk melihat keseluruhan permainan.

Dari beberapa kali hasil uji coba diatas, dapat disimpulkan bahwa permainan ini mampu memberikan pengalaman bermain dan belajar yang berbeda bagi anak-anak. Anak-anak diajak untuk mampu mengingat informasi yang ada dan secara cepat mereka harus dapat menjawab pertanyaan yang berkaitan dengan informasi yang mereka dapatkan. Dari hasil uji coba tersebut persaingan dapat terjadi antar pemain, namun persaingan tersebut menunjukkan bahwa anak-anak antusias.

\section{B. Saran}

Pengembangan media dapat dilakukan mengingat permainan dengan tema mitigasi masih mampu untuk dikembangkan lebih jauh dari segi konsep, tema, konten dan juga komponen. Pengembangan media menjadi berbagai macam bentuk sekunder sebagai alternatif media juga dapat dilakukan dan menjadi hal menarik dalam pengembangan penelitian. 
Pada penelitian selanjutnya disarankan untuk membuat mekanisme permainan yang lebih menantang untuk tingkat lanjut dan penambahan berbagai macam komponen yang memang diperlukan pada permainan damkar ini. Dan tidak menutup kemungkinan untuk penelitian selanjutnya dapat membuat seri permainan lain pada kasus bencana alam lainnya.

\section{DAFTAR PUSTAKA}

[1] Republik Indonesia 2010 "Surat edaran Kementerian Pendidikan tahun 2010 tentang RAN-PRB”. diakses tanggal 15 Oktober 2015.

[2] Nurjanah dkk. Manajemen Bencana. Bandung: Alfabeta (2012) 19

[3] Susan L. Cutter, Bryan J. Boruff and W. Lynn Shirle, Social Vulnerability to Environmental Hazards. (2003) vol. 84. 244

[4] Rismawati. Menstimulus perkembangan dan kecerdasan otak anak dengan permainan. (2002). Jakarta. 12.

[5] Sadiman, Dr. Arief S., M.Sc. Media Pendidikan: Pengertian, Pengembangan, dan Pemanfaatannya. Jakarta: PT. Raja Grafindo Persada. (2005) 2-3

[6] Azhar Arsyad. Media Pengajaran. Jakarta: Raja Grafindo Persada. (2000) 3 .

[7] Sadiman, Dr. Arief S., M.Sc. Media Pendidikan: Pengertian, Pengembangan, dan Pemanfaatannya. Jakarta (2006): PT. Raja Grafindo Persada. (2005) 28.

[8] Bramantyo. D. Finance, Risk and Management. Majalah Eksekutif edisi Juni 2006.

[9] Kompas media. "Permainan dan bermain cerdas bagi anak", edisi majalah tumbuh kembang anak, diakses tanggal 08 maret 2016. 